\title{
Vélib and data: a new way of inhabiting the city
}

\author{
Vélib e dados: uma nova forma de habitar a cidade
}

Dominique Boullier ${ }^{[0]}$, Maxime Crépe ${ }^{[b]}$

[a] PhD in Sociology, HDR in information and Communication Sciences, master degree in Linguistics, professor in Sociology at SciencesPo, CEE, Medialab, Paris - France, e-mail: dominique.boullier@sciencespo.fr

[b] Medialab, Sciences Po - Paris, e-mail: maxime.crepel@sciencespo.fr

\begin{abstract}
The Vélib bike rental system is worth analyzing in order to understand how cities move out of a model of large infrastructures towards a personal service principle connected to digital traceability and mapping of all activities. The new offer of bikes distributed all over the city creates a new map for access to mobility resources while introducing citizens to a "personal-public" device. Each feature of the system requires a very well designed information system to match the needs for bikes and to charge the users through cards (credit or transportation cards). Personal data is the essential entity that fuels the whole system and that creates potential privacy problems as well as monetization opportunities. The paper relies on a theoretical framework, called habitele, which accounts for the process of inhabiting that is now extended to the personal data ecosystem. The portability of mobile phones (and other devices such as cards) creates an envelope that follows the urban citizen and equips all his activities while it makes a new layer of the city appear, adapted to the personal involvement in the urban environment.
\end{abstract}

Keywords: Mobility. Bike. Personal data ecosystem. Habitele. Digital city.

\section{Resumo}

O sistema de aluguel de bicicletas Vélib é um caso interessante de análise para compreender a forma pela qual as cidades abandonam um modelo de grandes infraestruturas em favor do princípio de serviço individual, conectado à rastreabilidade digital e ao mapeamento de todas as atividades. A nova oferta de bicicletas, distribuídas pela cidade, cria um novo mapa para o acesso aos recursos de mobilidade, ao mesmo tempo que introduzem aos cidadãos um dispositivo "individual-público". Cada característica deste sistema exige um sistema de informação bem desenhado para corresponder à demanda por bicicletas e arrecadar dos usuários através de cartões (de crédito ou de transporte). Os dados pessoais são a entidade essencial que alimenta todo o sistema e gera potenciais problemas de privacidade bem como oportunidades de monetarização. $O$ artigo se baseia em um modelo teórico chamado 
habitele, voltado à análise do processo de habitação que agora é estendido para o ecossistema de dados pessoais. A portabilidade de telefones celulares (e outros dispositivos, tais como cartões) cria um envelope que acompanha o cidadão urbano e complementa as suas atividades, ao mesmo tempo em que engendra o aparecimento de uma nova camada da cidade, adaptada ao envolvimento pessoal no ambiente urbano.

Palavras-chave: Mobilidade. Bicicleta. Ecosistema de informação pessoal. Habitele. Cidade digital.

\section{Introduction}

The Vélib-type bicycle system is now quite common in cities around the world. Many of these cities decided during the last 10 years to follow the examples of Rennes (1998), Lyon (2005) and Paris (2007), trying to avoid the failures of Berlin's Call a Bike. The principle is a rather strange private-public partnership based on a contract between a private advertising company and the city governments. According to this contract, the city sells the billboards on the transportation systems in exchange for the installation and management of a network of stations renting bicycles at affordable rate. The contract may seem a strange transfer of rights and opportunities for these companies but it is a key feature of the data exchange that is required for operating the system reliably.

The landscape of cities has been changed by the installation of a network of Vélib stations where citizens or tourists can rent the bike for a short period of time for a very small fee. Identical bikes are parked in stations along the streets where anybody can rent them through a terminal. The user must insert his credit card, choose a password and he receives a one-day ticket, allowing him to rent a bike for 24 hours, by period of 30 minutes. Bikes are identified by a chip connected to the rack that detects when the user returns the bike. Frequent users can subscribe to the service for periods up to one year and simply scan their public transportation access card on the rack to identify themselves. The whole system is controlled by a central command center where all movements and status of bikes and stations are monitored using the chips' information as well as CCTV. All these new opportunities have transformed the behavior of urban inhabitants. The availability of inexpensive rental bicycles enables them to bicycle while avoiding the stress of bike ownership - bikes being the most commonly stolen object in urban environments.
This article focuses on the impact on behavior of the transfer of personal data into the operator's digital network, which creates a new access experience for inhabitants and other users of bikes. The analysis is based on a precise study of the technical system. It relies on observations and specifications, on a review of media and academic literature, of web conversations, and on participants' observations of users' behaviors. It was conducted during the habitele project, an international research project funded by the ANR (French Research Agency) that can be followed on the blog http://habitele.blogspot.fr/.

Access is not only a mantra for socio-technical visionaries such as Jeremy Rifkin: it is a major feature of the experience of inhabiting a city that depends strongly on the quality of the personal data sphere that is built around the user. This is why the conceptual framework of habitele (BOULLIER, 2011a, 2012) can help decipher the changes that are affecting the urban landscape and urban behaviors. Moreover it is an opportunity to reconsider the strong connection between habitele (based on personal data ecosystem), habitat (based on buildings and urban space) and "habitacle" (based on transportation bubbles that we create). These three dimensions of the human capacity to create interiors and to build envelops (as Sloterdijk, 2011, proposed it) will require, in the Vélib case study, to be very well designed and connected in order to produce the sought-after quality of urban experience. The neologism "habitele" seeks to account for the anthropological transformation we are experiencing, as two thirds of human beings have become equipped with a mobile phone ( 6 billion subscriptions, i.e. approximately 4.5 billion individual users, as of December 2011). This "connected being" status changes our mood, due to an alert state of mind; our everyday interactions, based on awareness more than presence; and our coordination skills, because of traceability. But it also offers the opportunity of switching between social worlds we are affiliated to 
- be it socio-demographic features or peculiar tastes that connect us to an ephemeral community. These affiliations create a new web of relationships, some of them supposedly private and others deliberately public, while these boundaries become increasingly blurred and challenge the rules of privacy. These affiliations may rely not only on mobile phones per se but also on other physical and virtual service access methods such as credit cards, keys, dedicated applications, and credentials of various kinds. Each of these possibilities is a common feature in mobile phones, but none of these has yet fully merged with the others in the device. This global environment of digital identities constitutes the habitele. Coining a new concept was required in order to avoid being trapped either in the innovation frenzy or in the repetition of postmodernist and individualist tropes. The concept of habitele is strongly connected to urban issues because it extends the human capacity of inhabiting to this web of digital affiliations, transforming, for instance, an individual into a "Vélib user", easily traced through the provider's service database.

\section{Urban mobility revisited}

Until recently, the solution to traffic congestion issues relied on the development of large technical systems that are known and labeled as public transportation systems. The problems of door-to-door service and of breaks in continuity remain unsolved. Every traffic manager knows that this is where the car still makes a difference. However, one key feature of the car tends to be underestimated and will be the main target of our demonstration of the relevance of habitele. This feature is the ability of the car to produce an envelope, which is experienced as a protection from the environment (natural, urban and social) as well as an extension of a habitat. Within it, personal tastes and preferences can be displayed, notwithstanding the apparent standardization of cars all over the world. This is an advantage no collective transportation system seems to be able to provide and this can be considered as one of the major explanations for the long lasting attachment to the car (FOUILLÉ, 2010). However the dream of a "personal collective" transportation system never disappeared, as B. Latour (1996) told us in his story of Aramis. Bikes, until recently, were not considered as capable of competing with the car, for various reasons, among which the effort required, the absence of protection of any kind, the failure of streets to adequately protect bike paths, the risk of theft, and so on. Although bicycling was valued as a sport, as contributing to better health, and as a very efficient and ecological mode of transportation (even in Illich's terms of general efficiency, Robert, 1980), bicycling in cities as an everyday practice remained difficult. Moreover it was often dismissed as either old fashioned or masochist. With the introduction of the Vélib-style system, we consider that the anthropological balance may have moved in favor of bikes as a means of mobility. The quality of the experience no longer depends on ownership and does not require a long-term engagement. Rather, it depends on there being a permanent display of opportunities through a very well designed distribution of Vélib stations throughout the urban space. The urban environment was changed in order to become a web of bikes stations, covering more densely the cities than the public transportation stations does and, by doing so, alleviating the liability of the door-to-door connection. "Your" bike is not in your courtyard anymore, for sure, but it is so easy to reach at the station next-door that you can build new strategies based on this availability. The visual display of this permanent availability is absolutely crucial for enhancing the attractiveness of the service and the trust in its reliability. Today the bicycle, although not owned, has become part of the inhabiting experience. It has become an extension of homes and workplaces, much like garages and parking lots. The issue of the quality of the envelope remains unsolved. There are no guarantees of quality, not even in the new design of the bikes used in these systems. The new bikes do not provide the user with any feeling of protection of an interior. On the contrary, the experience becomes one of detachment in which the user feels he or she is using a common or a publicindividual good (AMAR, 2010). What is required is a new sense of collective property. This sense is, however, constantly challenged by the high rate of vandalism against these public bikes (TIRONI, 2013). This is where the connection with habitele and the new design of the extensions of our selves through data and services become critical. Why?

Producing an envelope is not only a question of producing a physical container (as is the car) and not only a question of the legal extension of personal rights to some assets (as are property titles). It relies much more on the quality of the web created between 
the service provider, the technical resources (bikes and stations) and the users. In order to understand these links and their importance for the creation of a seamless experience, we must get into the details of the various mediations that contribute to these permanent connections. One key feature is that the chain of contributions must create a feeling of trust in the service and of reliability from the technical and legal points of view. Trust becomes the result of the various arrangements that are so well sealed that they become natural or taken for granted (SCHUTZ, 1962). At the moment, the access itself might be considered as transformed into a permanent resource of the individual. The extension of one's sphere of influence becomes visible through these bike systems. However, to achieve this "society ready made", one must account for the work of each specific link, for the "society in the making", to use the terms designed by Bruno Latour (2005). This article will focus on the following technical architectures that are all an intrinsic combination of physical intervention and qualities and data flows, in which habitele can be reconsidered and tested, not as a separate field (the world of data, the cloud, the intangible and so on) but as a very effective grip on the world in all its aspects.

\section{The web of stations in the city and the web online: how they cooperate to distribute bikes through the city}

Let us start by the more visible and fascinating quality of this system--the distribution of bikes stations throughout the city and their (supposed) permanent capability of offering a bike to any potential user. This problem of reliable availability cannot be solved simply by carefully designing a dense network of stations. There are 1,800 Vélib' stations distributed throughout Paris and in the 30 surrounding communities (this compared to 298 metro stations in Paris) with an average distance of 300 meters between stations. How can a service that relies for its efficiency and cohesiveness on the behavior of so many individuals guarantee the appropriate distribution of the 23,000 bikes so as to ensure bikes are available for the next users? If such a system model existed, it would be a powerful demonstration of the emergence of equilibrium in complex systems but, unfortunately for utopians, this is not the case. Bikes are used following specific patterns where, for instance, the ones on the top of the hill are more frequently used while almost nobody cares about cycling back uphill, and some destinations are more attractive than others. In addition ridership is affected by ever changing weather conditions. Of course, the service tries to reward good practices and allocates a bonus of 15 minutes to the bikers who would leave their bike at a bonus station, but this moral system cannot ensure the appropriate distribution of the resource. This coordination work - or articulation work as Anselm Strauss et al. (1985) put it requires a very well informed and reactive service of bike redistribution among the stations. This means there must be trucks to carry the bikes back up the hills or elsewhere in the peripheral areas, staff (160 people in Paris not including maintenance agents), and information systems able to track down the occupation status of any specific station and to transfer the information, to compute the resources available and to allocate them following a model of users' behavior. The importance of this maintenance work is well understood by urban managers because it is critical to users' (who are also voters) satisfaction. And every missed link reduces trust in the service, which leads users to exit the system without expressing their "voice" (HIRSCHMANN, 1970) to the help desk. The distribution of bikes must be rearranged frequently to fit with future users' behavior so that the feeling of continuity of the service is maintained. This level of quality is obtained through sophisticated databases. The efficiency of mathematical models is undermined by the instability of individual behavior, which is very sensitive to weather, events, and so on (TIRONI, 2013). While modeling was supposed to fully describe patterns of bikers' behaviors, it appears that the most important improvements depend on the local expertise of the staff that reallocates the bikes in the stations with their trucks.

Another link seems rather underestimated: the expertise of users and their connection to the information systems. By not accounting for this link, the system appears not to have any relationship with the personal data ecosystem, which is at the core of our habitele model. However, companies process a huge amount of personal data, i.e. all the traces we create by our digital activity. The database and the models are ineffective unless they are fueled by the extensive traces of every bit of users' mobility. Biking is no longer simply using a bike, it means being tracked down 
for each segment of trip (the basic fee limits the use to 30 minutes) and accepting it. We shall come back to the issues of privacy that arise immediately, but at this point, the technical part of the process of coordination is our main focus. Providing a system with this kind of data is not optional, it is the prerequisite for the use of the bikes because no one can unlock a bike without interacting with the terminal, through various interfaces, depending on the kind of subscription that was adopted. Access to the service means giving access to information about your behavior to the service information system; there is no other way to gain the power of biking whenever you want. Is it any different in the case of other transportation systems? Yes, but it is a rather small difference, because many non-usual commuters can use tickets that are anonymous while, for the bike rental systems, they must use their credit card and obtain a ticket which delivers a personal status (including a personal code). Is there any difference with cars? Yes, and a huge one, because car drivers do not give any information to any authority about their destinations and nobody can track them (a freedom which is not guaranteed by NSA anymore). Is there any difference with the web of data surrounding the use of a private bike? Yes, because the data commonly used are maps and GPS services to locate areas of interest but not specifically related to the bike. To a certain point, it would be easy to argue that private bikes are the less traceable devices (no plates, no license, no fuel, no tax and no electronic system of any kind). In that sense, private bikes contribute to the extension of the personal data ecosystem. They do not create a new digital envelope of their own, and for some users, it can be considered as good news. So, this is our first point: creating this extension of resources for citizens requires that they agree to have their data incorporated in the bike services' information system. This is where the bike rental system becomes not so much a public transportation system as a new protocol for delivering access services. The two webs (the one of stations and the one of information) are connected through the use of terminals located at the stations. Their management differs but each relies on the other. Users are involved in both and generate flows of bikes as well as flows of data, although operators whose job is not exactly equivalent to the models implemented in the information system rearrange the bikes on the field.

\section{Occupation of physical space and of digital cells}

Another feature modifies the material dimension of a city. Space is a rather scarce resource and competition between various uses is frequent. The decision to allocate some space for installing bikes stations or for creating bike paths on the streets means not only cutting down the influence of cars on the city design but also modeling and predicting the behavior of people who might be interested in the service in order to select the best spots and to distribute them all over the city. One important use of the information system will consist in testing the relevance of the models and assessing the weakness of some choices previously made, in order to redesign the distribution itself. As Tironi (2013) explains and as we said, those models cannot account for rather whimsical behavior, influenced by a number of parameters that seem difficult to combine, at least in linear logical models. Even though applications dedicated to tracking the behaviors of station-users can be displayed in a fancy way, they do not provide sufficiently sophisticated patterns for improving the service.

In the meantime, the intensive tracking process creates an opportunity for users to use data localization on their phones in real time. Access is not only a question of rights, when equipped with an efficient information system made available through smartphones applications. The average user is able to orient himself in the city with the permanent display of the resources located in his close environment. Applications map the proximity of bikes stations as well as the number of bikes available. More than 40 of these applications are available for free or sold on the Android market, some dedicated only to Paris and others to many cities in France and in the world. This is a major change in public transportation policies in which the service is not only produced in generic terms but can be described from the point of view of the user, from his GPS location information, and in real time. The user experience itself changes thanks to these location devices and not only thanks to bikes. By using a GPS on one's phone, one can rearrange the whole city according to one's interest of the moment and to make the relevant service pop up instantly in the neighborhood although it was almost invisible a minute before. This is why this service is especially useful for locating bike stations that are not visible on main streets. The 
availability issue is solved for the spatial aspect of it. But access is also a question of "kairos" (the god of the right moment), of time, since traffic generates flows of activity and permanent changes in the status of the resources. This is true for buses or metros, for which one needs to know not only the location of the nearest station but also the frequency of trains. However this real time information is still seldom available to users. In the case of bike stations, this information makes different tactics of mobility in the city possible and creates a sense of belonging to a living technical system, in which the user is really the target and not only the recipient of traffic information along predicted routes. The city seems to rearrange itself around individual points of views and moments of activities.

Also, the interface itself produces an interesting shift in a person's relationship with the city. Maps are now the common frameworks for orienting oneself in the city. It was meant to be the case before, but rarely was, due to the problem of auto-reference and placement of one's personal position. This situation explains the importance of the "you are here" feature, a prerequisite to begin the investigation in physical maps in urban space. There is no such problem with GPS, as anyone becomes the center of these dynamic maps, always focused on the real position of the user. It may seem a very limited change. But, in fact, the penetration of cognitive technologies in everyday life is a very important one. Maps are experienced as maps-for-action and create a common knowledge we label as "folkmapping" (BOULLIER, 2011b), in reference to folksonomies (CRÉPEL, 2008). Their pervasiveness in all applications reveals how they have become more powerful than any language description. The city and its representation are becoming increasingly user-centered, focusing on the citizen, at least the one who is equipped with those smartphones and GPS tools. But the pervasiveness of maps on mobile phones reaches such an extent that it might become the main interface for orientation and searching, something Google understood a long time ago therefore investing in Google maps and street view, greatly, which affected the relationship to the city as an uncertain environment. There is no longer room for surprises, expectations, or confusions. The average user now knows exactly where the next bike stations are, their appearance, and how many bikes are available. This is also the case for restaurants, cinemas and many other services connected to GPS, maps and street views. These applications really gain momentum only when used on the cell phone, strongly connected to the body and to its situated environment. They create this bubble effect typical of habitele. Of course, this is not specific to bike systems but the connection to a service as complex as this bike rental service requires such an efficient application. This is another link which is both mandatory for the service to be delivered (offer) and critical for providing a rich experience of immersion and control in the city (demand). Of course, the counterpart is that every user agrees to provide the service with all personal information that might be associated with the GPS application dedicated to the bike system. And the wheel goes on, since it produces more data for the information system to process, model and disseminate to other processes and so on.

\section{Maintaining bikes and designing interfaces}

Another key feature of the quality of service is the maintenance of the bikes themselves. Vélib bikes are produced in Hungary by the French bicycle company Mercier and are maintained by JCDecaux. The price per bicycle ranges from 300 to 650 euros. They are three-speed bicycles, each weighing approximately 22.5 kilograms. Vélib bikes are equipped with always-on LED lighting powered by a fronthub dynamo, a locking system, and a basket on the handlebars. These technical features are significant and the result of many deliberate and controversial decisions. They assume an implicit model-user as Eco put it for the reader, including a specific style of use. Maintenance also requires a contribution from the user who is not supposed to use the bikes in ways that would damage their performance. However there are many situations where users, deliberately or not, give back out-of-order bikes and there is no way to inform the service provider, even if one intended to do so. This is the flip side of the common good style: a person feels no responsibility at all for the maintenance, which means a high cost for the service provider. In Paris, in 2010, under the terms of the city's contract with the operator, the cost of bike thefts was charged to the city. This trend in public behavior was enhanced by a cultural evolution specific to inner-city youth, in which stealing a Vélib becomes an initiatory ritual to be performed. 
This is an important aspect for habitele and habitacle, because the shift to a common good status is still connected to individual use and the absence of a feeling of property can lead to a failure to take care of the habitacle. Because one cannot identify with or appropriate the resource, one may lack the minimum civic mindedness to feel responsible for a common good. However, this is something that could be improved using the digital network capacities. This could be a part of the empowerment of the users' community if a service like "see click fix" were created for any user to get connected to a general trouble report system. It would value the contribution of average citizen to the common good and invent a new cycle of maintenance based on more collective responsibility.

Another aspect of the system design can be critical. The model-user was not created only for the bikes features but also for stations and connection features. The interfaces were carefully tested and seek to accommodate many different styles of uses and to allow non-expert users to get familiar with the service. However, the length and the complexity of the process for those using it for the first time remain an obstacle to the expansion of the community of users. This is why access becomes fluid only when one has a Navigo pass (the general transportation pass in Paris region) or a Vélib card and allows the user to place its card in contact with a bike rack and to retrieve the bike immediately. The long-term user uses these cards equipped with a RFID chip, contactless smart cards using the Calypso standard1. Through antennas and waves, the connection may look immediate and create this fluid experience of being a member of a club or a quasi owner of the service, using bikes whenever one wants.

This contrasts with the five-minute process required for non-registered users. Habitele is based precisely on this process of habituation, of naturalization of relationships with the environment. The comparison is interesting between the frequent and registered user on the one hand and the newbie or unregistered one on the other hand. These model-users are quite different and the gap in user-friendliness is huge. The registered user is so well incorporated in the information system that he is experiencing the pleasure of being a member, of being within, of the quasi disappearance of boundaries between him and the technical system. It is only when one can observe the work required for the non-registered user that the natural status of the coupling to the system reveals the whole process that had to be performed in order to achieve this "taken for granted" status, as Schutz (1962) labeled it.

\section{The credit card as the key ID}

Now let us focus on a third mediation that is clearly relevant for habitele: the credit card payment and the consequences in terms of personal data that are exchanged stored and processed. The experience of a frequent user, where there is no further need for registration, contract and interface manipulation, is a compact process--the most condensed one. In contrast, the first time user will feel trapped in a long and complex procedure in which the credit card is a key resource. One must accept this rule: no credit card: no use of the bike service. It means relying on another technical system, supposedly widely shared, and so taken for granted that it does not dissuade users. The moment one enters this area of data exchange based on a credit card, a very well designed social world is revealed and mobilized. Credit card traditions took 30 years to become shared among the French population, and a specific version of it, the one with a chip embedded in the card, was invented by Moreno...in France during the seventies. This system (Visa and Mastercard are the global networks that constitute the oligopoly of this financial transactions industry) seems to be destined to extend to the entire world, although there are some variations and restrictions regarding the full digitization of the transactions (paper slips still have to be signed in many countries). This process is as important to understanding what we call the "personal globalization" as the global dissemination of cell phones over a 15-year period. Credit cards effectively lower national boundaries because national currencies are no longer required for financial transactions. The credit card, a personal device, attached to one's personal bank account, can travel across borders and has become essential in many situations. However, over-reliance on a credit card may create problems depending on local practices regarding the implementation of digital currency. Now that the use of credit cards is taken for granted for any kind of transaction, even 
on-line ones, regardless of the serious flaws in data security, there is no use questioning the implementation of a service such as the bike rental system. It is fully depending on this system, although the costs at stake are very low: $€ 1,5$ for the first half hour, that can be reproduced for free all day long, provided that the duration of the rent does not exceed half an hour, each time. What we have here is the success story of the extension of habitele through the naturalization of a specific means of payment. Achieving this result required a great deal of work designing terminals, reaching agreements between various partners about legal and financial aspects, and building confidence largely through very powerful insurances policies. The reliability of this system, especially by eliminating users' concerns about fraud, is impressive, even though it was achieved at a cost for all transactions. Most users largely ignore this transaction cost because it is so well distributed and limited. This extension of the habitele contributed to an important change in the implementation of local branches and bank offices for the public. Downtown offices and branches have been reduced to ATMs, available 24/7 thus avoiding office labor costs. The entire geography of access to banking services has been changed as a result of this invasion of credit cards requiring ATMs throughout the city. Habitele (which includes credit cards) is not just personal equipment. It affects the whole infrastructure of access. This is why it is always a transactional concept, helpful in accounting for the design of the material environment, and not just a personal data ecosystem.

When the bike service was implemented, it simply extended the proliferation of some kind of ATMs, in this case dedicated to a specific service. All automated terminals designed to buy and sell transportation tickets, fuel, and so on, operate as do ATMs, without any interaction with a human being. However, the bike service also involves a connection to one's personal banking information that is usually very critical and sensitive. This is especially so because the amounts at stake are not only the small fee we mentioned before, but also the deposit required to guarantee the return of the bike. At the time of this writing, an amount of 150 Euros is blocked as a deposit and will be cancelled only when the bike is returned albeit with a small delay of two days. This delay has been criticized by consumer associations which argue that for low income users using the system every day, the amount of the deposits can be cumulated to a point where they exceed the limits specified in the user's contract with his bank. The problem might not seem very significant but it shows that a technical system like the bike rental one cannot work without a strong and permanent flow of information from banks and at an individual level. In today's urban setting the main ID that serves as a reference and a guarantee is not the identity card or the passport, but the credit card. Credit cards are considered much more reliable especially when money transactions are involved because of all codes and controls involved. Individuals are now supposed to be equipped with a credit card, and to know how to maintain their right to use them.

\section{Personal data and the facets of the user}

This bank guarantee behind the use of the credit card can be transferred to a personal contract with the provider. At this time, personal data, including banking data, are delivered to the system, through the web site at the moment the subscription is signed. The move to the web site for contract signing might be feasible through a mobile phone. However, this is not the kind of operation one usually does in the middle of the street, since a lot of personal information is required. Two types of subscriptions are proposed according to duration of the rental (45 minutes or 30 minutes) with a different rate ( $€ 39$ vs 29 ). With this subscription, the user agrees to become a member of a "clientele", which requires him to wave all restrictions on his personal data. At the beginning of the service with JC Decaux Company in 2007, the City of Paris was required to comply with the legal agency in charge of controlling information systems and database since 1978 (CNIL: "commission nationale informatique et libertés"). The CNIL required many changes in order to improve the privacy rules while using personal data:

- Location data connected to a personal account are saved only for long-term subscribers and not for short-term tickets users.

- Data required for the management of the subscription are saved and stored for 24 months except for validation data. 
- For long-term subscriptions, data related to the routes used by the bikers are anonymized once the duration of the trip has been calculated. Longer trips (over 30 minutes, therefore charged) are saved during 5 days in order to give the user the opportunity to contest the bills.

- Although the Navigo pass can be used for both bikes and public transportation, the connection between the 2 systems was not accepted.

These rules are mandatory and limit abusive intrusion into personal activity, which would be possible given that all permanent personal data can be related to real activity tracked by the information system. However, users must trust the service provider while they know that for commercial purposes it is critical to use CRM techniques (Consumer Relationship Management) and to follow the behavior of segments of the population. This follow-up has been possible since May 2013 when an Open Data policy was settled, provided that these data are only aggregated and anonymized ones. The value of this information (requests, uses, itineraries and so on) built on users' traces has become a hot issue among urban services providers and city managers. The trend towards open data systems is supposed to be inevitable but it remains a controversial issue for many cities and service providers. First this information must be processed as anonymous data. However, no one can really guarantee this request for privacy, since interconnection of behavioral traces may produce new opportunities for identifying people. And second, the ownership of this data is strongly disputed, some providers considering that this is a gold mine produced by their own service and not supposed to be shared by any other potential competitor. This is why only very general datasets are made available offering very few opportunities to invent really new and useful services for any other company.

The habitele of the user produces various layers that are still related to his personal engagement in the world but offering different facets of his status. As a client, he cannot deny the service provider access to his personal data. As a legal person with rights, the national authority protects him from database misuses. As an agent in a collective activity, he is computed as a dot moving from one station to another without any attributes. In this last avatar, he becomes an element in a model or in a dataset that will be used for various purposes, some of which are not related to the bike activity, since these data may account for other patterns interesting other fields of business (for instance to decide the location of shops) or of civic interest. This is a good opportunity to tear down the supposedly "person-centered model" of "personal data ecosystem" and to move to a habitele approach: depending on the facets of profiles that are relevant, the data exchanged are different to the point where the connection with legal personal features can disappear. There is no such thing as a kernel of the "person" but only engagement in relationships. When carefully checked on the site of the service provider (https:// developer.jcdecaux.com/\#/opendata/vls), the open data are only statistics related to the stations, or dynamic data related to the number of bikes available. In this format, the user as such disappears and is just the hidden agent of modifications in the allocation of resources. Bikes are the basic entity tracked, but they still have a relationship with the user who is the only one to make them move (apart from the maintenance team). One can say that in the bike rental system, bikes are the users and speak for themselves, because, due to legal constraints, there is no way to access the IDs of their users. In some ways, this situation is common to any retail activity or public transportation one that does not have any in-depth information about who their customers are. They only have the results of their users' behavior in the flow of goods, the occupation rate and the traces of entrance controls. Sometimes, the data are augmented by various kinds of surveys in order to represent the phantom public (LIPPMANN, 1927) and to translate it into "intermediary beings" (BOULLIER, 2010), the ones operated by the system.

\section{Conclusion}

We followed the major mediations that make the system work and comply with the habitele cohesiveness. It appears that although service providers are mainly guided by technical efficiency and financial benefits, they cannot avoid looking for a seamless system that deeply changes the experience of the city. This is where the habitele model helps us understand what is at stake: the production of an envelope that 
will encompass physical delivery of a service as well as the digital flow of data. Both must have to be designed along the same principles of accessibility so that the rental experience becomes transformed into a taken-for-granted extension of available personal resource. Each mediation is a two-fold one, having its counterpart either in the physical or the digital world. This is why the description itself must avoid any separation of these areas that are as closely related as are sounds and meanings (signifier and signified) in language. The city as such, the one made of concrete, is now duplicated and of course translated (CALLON, 1986) into flows of data. The interconnection of both is critical when talking about quality of services and of experiences. This is why the design of habitacle and the one of habitele are so closely related in the case of Vélib service delivery. Inhabiting a car or a bike rental system and a dataset do not seem equivalent, but as we tried to demonstrate, the processes at stake are the same and the skills relate to our expertise in transforming the world to "become within" (BOULLIER, 2013).

\section{References}

AMAR, G. Homo mobilis, le nouvel age de la mobilite, eloge de la reliance. Paris: Editions FYP, 2010.

BOULLIER, D. Habitèle virtuelle: une nouvelle enveloppe pour commuter, notre téléphone portable. Revue Urbanisme, n. 376, p. 42-44, 2011 a.

BOULLIER, D. From GIS to folk mapping and datascapes. In: INTERNATIONAL CARTOGRAPHIC CONFERENCE, 25., 2011, Paris. Proceedings... Paris: International Cartographic Association, 2011b.

BOULLIER, D. From personal data ecosystem and mobile phones to the general theory of habitele. Invited talk in UC Irvine, May 18th 2012, Institute for Money, Technology and Financial Inclusion. Available at: <http:// stream3.es.uci.edu/tltc/Production/IMTFI/20120518_ Boullier.html>. Accessed in: Oct. 24 2013.

BOULLIER, D. Cosmopolitics: to become within, from cosmos to urban life. In: COLLOQUE WHAT IS COSMOPOLITICAL DESIGN, 1., 2013, Princeton. Proceedings... Princeton: Princeton University School of Architecture, 2013. Available at: <http://soa.princeton.edu/content/what-cosmopolitical-design>. Accessed in: Oct. 24th 2013.
BOULLIER, D. Le client du poste téléphonique: archéologie des êtres intermédiaires. In: CALLON, M. Débordements. Paris: Presses de l’Ecole des Mines, 2010. p. 41-61.

CALLON, M. Some elements of a sociology of translation: domestication of the scallops and the fishermen of St Brieuc Bay. In: LAW, J. (Ed.). Power, action and belief: a new sociology of knowledge. London: Routledge \& Kegan Paul, 1986.

CREPEL, M.Les folksonomies comme support émergent de navigation sociale et de structuration des données du Web. Réseaux, v. 26, n. 152, p. 169-204, 2008.

FOUILLE, L. L'attachement automobile mis à l'épreuve: étude des dispositifs de détachement et de recomposition des mobilités. 2010. 476 f. PhD thesis (Ecole doctorale Sciences Humaines et Sociales) - University of Rennes, Rennes, 2010.

HIRSCHMAN, A. O. Exit, voice, and loyalty: responses to decline in firms, organizations, and states. Cambridge, MA: Harvard University Press. 1970.

LATOUR, B. Aramis, or the love of technology. Cambridge, MA: Harvard University Press, 1996.

LATOUR, B. Reassembling the social: an introduction to actor-network-theory. Oxford: Oxford University Press, 2005.

LIPPMANN, W. The phantom public. New York: Simon \& Schuster, 1927.

ROBERT, J. Le temps qu'on nous vole. Paris: Seuil, 1980.

SCHUTZ, A. The phenomenology of the social world. Evanston: Northwestern University Press, 1962.

SLOTERDIJK, P. Bubbles: spheres volume I - Microspherology. Cambridge: MIT Press, 2011.

STRAUSS, A. et al. Social organization of medical work. Chicago: University of Chicago Press, 1985.

TIRONI, M. La ville comme expérimentation: le cas du Vélib' à Paris. 2013. 467 f. PhD thesis (sociologie de l'innovation) - Ecole des mines de Paris, Paris, 2013.

Recebido: 15/09/2013

Received: 09/15/2013

Aprovado: $18 / 10 / 2013$

Approved: 10/18/2013 